\title{
A Comparative Study of Effect of Interval and Continuous Training toward Oxidative Stress Level, Antioxidant Enzyme Capacity, and Resistance of Erythrocyte Membrane
}

\author{
Moch.Yunus \\ Sport Science Faculty \\ Malang State University \\ Malang, Indonesia \\ moch.yunus.fik@um.ac.id
}

\author{
E. S. Wahjuni \\ Sport Science Faculty \\ Surabaya State University \\ Surabaya, Indonesia \\ endangwahjuni@unesa.ac.id
}

\author{
N. R. Fadhli \\ Sport Science Faculty \\ Malang State University \\ Malang, Indonesia \\ nurrul.riyad.fik@um.ac.id
}

\begin{abstract}
--this study examined the effects of interval and continuous trainings on decrease in the oxidative stress level, increase in the antioxidant enzyme capacity and increase in the resistance of erythrocyte membrane. The research was done randomly in group pretest and post-test design of 40 students in Sport Coaching Education, Sport Science Faculty, and Malang State University who were divided into two groups, that is, interval and continuous training groups. Research subject was taken with Purposive Randomized Sampling. They were trained 3 times a week, for 8 weeks with moderate intensity and 30 minutes for exercise. Data was collected by measurement technique of blood samples, that is, blood plasma MDA level, as indicator of oxidative stress level, blood plasma SOD activity as indicator of antioxidant enzyme capacity and osmotic fragility of erythrocyte as indicator of resistance of erythrocyte membrane. The results of Data analysis by use of MANOVA, with $\alpha \mathbf{0 , 0 5}$, concluded that the interval and continuous trainings decreased the oxidative stress level and increased both the antioxidant enzyme capacity and the resistance of erythrocyte membrane with no significant influence differences between interval and continuous trainings toward dependent variables mentioned above.
\end{abstract}

Keywords--training, oxidative stress, antioxidant enzyme, resistance of erythrocyte membrane.

\section{INTRODUCTION}

Sport training has been known to have many benefits for health and physical fitness. Besides being able to increase the cardiovascular fitness, several research results showed that sport training with mild intensity, is able to inhibit infectious diseases, cancer, and the risk factor of cardiovascular, diabetes, and osteoporosis [1]. Corbin, et al stated that sport training, if done regularly, is able to increase the health level and is able to help someone to prevent diseases. It can become part of medication towards diseases [2]. Physiologically, training limits physical stress to the body that enables produce adaptation responses. Physical training is suggested as far as the body is able to adapt with the given excessive load. Training in high intensity is able to induce specific adaptations that enables the body to function efficiently.

Sport training will also produce free radical. It is caused by training and is able to increase the oxygen up to 20 times and the muscle up to 100 times. The sport training may lead to ischemic perfusion. During sport training, temporary hypoxia may occur at several organ tissues that are not active such as kidney, liver, and intestines. Sport training with high intensity with maximum arterial pulse from $80-85 \%$, may cause the tendon fiber to become hypoxia because, during the training, the muscle contracts strongly, squeezes the intramuscular blood vein in the active muscle, which causes the blood flow to decrease to the active muscle. After training is finished, the blood is back to various organs that lack blood flow, so reperfusion occurs that causes several free radicals in the circulation. [3]. Maximum sport training causes metabolism increase in the body. The oxygen use increases especially by the contracted muscle, hence causing an increase in the electron leak from the mitochondria that become free radicals [4].

Sport training adaptation is also known to produce antioxidants, such as catalase (CAT), superoxide dismutase (SOD), and Glutathione Sulfur Hydroxyl (GSH) [5] [6]. Antioxidant defense is needed for a cell, because cells will continue to form oxygen freeradicalsthat is, reactive oxygen species (ROS) during the respiration process or inflammation condition [7]. The excessive free radical production in the body triggers the condition called oxidative stress. Malondialdehyde (MDA) is the end product of fat peroxidation used as biological biomarker. SOD enzyme is the main endogenous antioxidant that has important role directly in protecting the cell from free radicals, and indirectly maintain the oxygen balance that is toxic in nature [8].Erythrocyte is a very vital body cell and it is also prone toward free radicals. The formed antioxidant in the erythrocyte is superoxide (O.2-), Hydrogen peroxide (H2O2) and peroxyl radical (ROOD.). The free radical source can come from 1) The increase of auto oxidation process of Haemoglobin $(\mathrm{Hb})$ becomesmethemoglobin, 2) The increase of electron transport system in mitochondria, 3) The built up of lactate acid, 4) The increase of xanthine oxidase (XO), and 5) The increase of catecholamine production [9].

The research is done to know the adaptation response of training sports towards free radical production and the antioxidant activities with varied results. Several researches showed that training is able to increase the free radical production significantly, while several other researches showed the contrary. It is influenced by several factors, such as, training program differences, cell type measured, research subject and measurement method. The difference in the 
training program causes different results in the free radical production. It relates with the intensity and training duration. The research was done to know the training adaptation towards the oxidative stress level decrease and the increase in both antioxidant capacity and resistance erythrocyte membrane.

\section{METHOD}

This research is a quasi-experimental, with a randomized group study design pretest and post-test design. The research population are students of Sport Training Education Department, Sport Science Faculty of Malang State University Force 2015/2016 of 92 people. Research subject taken with Purposive Randomized Sampling, is 40 persons divided into two groups, that is, interval and continuous training groups. They were trained with frequency of 3 times a week, for 8 weeks with moderate intensity and 30 minutes for exercise duration. At the beginning, before the training program and after the training program has ended, the blood samples taken from their veins were collected in EDTA coated tubes for analyses of MDA level as indicator of oxidative stress level, SOD activity as indicator of antioxidant enzyme capacity, and osmotic fragility of erythrocyte as indicator of resistance of erythrocyte membrane.

Data were analyzed by Multivariate of Analysis Variance (Manova). Analysis technique employed was that of Manova including data normality test (Shapiro-Wilk technique), and variant homogeneity test in group (Levene's technique). The data was analyzed by using SPSS Version 23 and testing by using $\alpha 0.05$.

\section{RESULT}

TABLE I. DESCRIPTION OF DATA INTERVAL AND CONTINUOUS TRAINING MEAN \pm SD

\begin{tabular}{|c|c|c|c|c|}
\hline \multicolumn{2}{|c|}{ Variable } & Pretest & \multirow{2}{*}{$\begin{array}{r}\text { Posttest } \\
870,00 \pm \\
42,89 \\
\end{array}$} & \multirow{2}{*}{\begin{tabular}{l}
\multicolumn{1}{c}{ Delta } \\
$\begin{array}{c}\text { ( Posttest } \\
\text { Pretest) }\end{array}$ \\
$-71,50$ \\
36,46
\end{tabular}} \\
\hline $\begin{array}{c}\text { MD } \\
\text { A }\end{array}$ & Interval & $\begin{array}{ll}941,50 & \pm \\
46,86 & \\
\end{array}$ & & \\
\hline $\begin{array}{l}\text { (ng/ } \\
\mathrm{ml})\end{array}$ & Continuous & $\begin{array}{l}1000,80 \pm \\
81,66\end{array}$ & $\begin{array}{ll}865,75 \quad \pm \\
18,97 & \\
\end{array}$ & $-135,00 \pm 85,2$ \\
\hline \multirow{2}{*}{$\begin{array}{c}\text { SOD } \\
(\mathrm{U} / \mathrm{m} \\
\mathrm{l})\end{array}$} & Interval & $18,77 \pm 2,23$ & $32,80 \pm 2,78$ & $14,03 \pm 2,56$ \\
\hline & Continuous & $21,78 \pm 2,60$ & $34,03 \pm 1,23$ & $12,24 \pm 3,00$ \\
\hline \multirow{2}{*}{$\begin{array}{l}\text { OF } \\
(\%)\end{array}$} & Interval & $0,45 \pm 0,02$ & $0,42 \pm 0,02$ & $-0,03 \pm 0,03$ \\
\hline & Continuous & $0,46 \pm 0,02$ & $0,43 \pm 0,02$ & $-0,03 \pm 0,03$ \\
\hline
\end{tabular}

Based on Table 1, it Showed mean \pm standard deviation (SD) of pretest, post-test and delta (posttest - pretest). The dependent variables, consists of: 1) Blood plasma MDA level as indicator of oxidative stress level, 2) Blood plasma SOD activity as indicator of antioxidant enzyme capacity and 3) Osmotic fragility of erythrocyte (OF) as indicator of resistance of erythrocyte membrane.

TABLE II. SUMMARY OF MANOVA ANALYSIS RESUlTS OF DEPENDENT VARIABLES

\begin{tabular}{|l|l|l|l|}
\hline Effect & F & Sig & Explanation \\
\hline Interval training & 103,3 & 0,000 & Significant \\
Continuous training & $39,711^{\mathrm{a}}$ & 0,000 & Significant \\
$\begin{array}{l}\text { Delta interval }- \\
\text { continuous trainings }\end{array}$ & 1,075 & 0,403 & Not significant \\
\hline
\end{tabular}

Based on Table 2, interval training obtained there is dependent on variable component between pretest and post-test and differs significantly $(\mathrm{p}<0,05)$, Continuous training obtained is dependent on variable components between pretest and posttest and differ significantly $(\mathrm{p}<0,05)$ and in Delta (post-test - pretest ), the dependent variable between interval training and continuous training are not different significantly $(\mathrm{p}>$ $0,05)$.

\section{TABLE III. ANALYSIS RESUltS OF SIMULTANEOUS CONFIDENCE INTERVALS DELTA INTERVAL AND CONTINUOUS TRAININGS}

\begin{tabular}{|c|c|c|c|c|c|}
\hline \multirow{2}{*}{$\begin{array}{l}\text { Dependen } \\
\text { t Variable }\end{array}$} & \multirow{2}{*}{$\begin{array}{c}\text { TRAININ } \\
\text { G }\end{array}$} & \multirow[b]{2}{*}{ Mean } & \multirow{2}{*}{$\begin{array}{l}\text { Std. } \\
\text { Error }\end{array}$} & \multicolumn{2}{|c|}{ 95\% Confidence Interval } \\
\hline & & & & $\begin{array}{l}\text { Lower } \\
\text { Bound }\end{array}$ & $\begin{array}{l}\text { Upper } \\
\text { Bound }\end{array}$ \\
\hline \multirow[t]{2}{*}{ dMDA } & Interval & -71.500 & 16.637 & -106.454 & -36.546 \\
\hline & Continuous & -98.000 & 16.637 & -132.954 & -63.046 \\
\hline \multirow[t]{2}{*}{ dSOD } & Interval & 14.029 & .882 & 12.176 & 15.882 \\
\hline & Continuous & 12.245 & .882 & 10.392 & 14.098 \\
\hline \multirow[t]{2}{*}{$\mathrm{dOF}$} & Interval & -.028 & .009 & -.046 & -.010 \\
\hline & Continuous & -.028 & .009 & -.046 & -.010 \\
\hline
\end{tabular}

Based on Table 3, it can be presented that all vector components do not contain zero value. This means that interval training and continuous training gives influence at the oxidative stress level decrease and increase in both antioxidant capacity and resistance of erythrocyte membrane.

Statistically, there is no significant differences in the influence between interval training and continuous training toward dependent delta variable. This means that the research results of the difference effectiveness of the influence between interval training and continuous training can't be generalized at population. To know how much the difference effectiveness of the training influence toward the four dependent variables is in the research, it can be seen in table. Table 4 below.

TABLE IV. RESULTS OF EFFECTIVENESS ANALYSIS OF DEPENDENT VARIABLE AT INTERVAL AND CONTINUOUS TRAININGS IN THE RESEARCH SAMPLE

\begin{tabular}{|c|c|c|c|c|c|}
\hline \multicolumn{2}{|c|}{ Variable } & \multirow{2}{*}{$\begin{array}{l}\text { Pre-test } \\
\\
941,50 \quad \pm \\
46,86 \\
\end{array}$} & \multirow{2}{*}{$\begin{array}{l}\text { Post-test } \\
870,00 \pm \\
42,89 \\
\end{array}$} & \multirow{2}{*}{$\begin{array}{l}\text { Delta } \\
-71,50 \\
\pm 36,46 \\
\end{array}$} & \multirow{2}{*}{$\begin{array}{c}\begin{array}{c}\text { Explana } \\
\text { tion }\end{array} \\
\downarrow 7,59 \%\end{array}$} \\
\hline $\begin{array}{c}\text { MDA } \\
(\mathrm{ng} / \mathrm{ml})\end{array}$ & Interval & & & & \\
\hline & $\begin{array}{c}\text { Continuo } \\
\text { us }\end{array}$ & $\begin{array}{l}1000,80 \pm \\
81,66\end{array}$ & $\begin{array}{ll}865,75 \quad \pm \\
18,97\end{array}$ & $\begin{array}{l}- \\
135,00 \\
\pm 85,2\end{array}$ & $\downarrow 13,49 \%$ \\
\hline \multirow[t]{2}{*}{$\begin{array}{c}\text { SOD } \\
(\mathrm{U} / \mathrm{ml})\end{array}$} & Interval & $\begin{array}{c}18,77 \pm 2,2 \\
3 \\
\end{array}$ & $32,80 \pm 2,78$ & $\begin{array}{c}14,03 \pm \\
2,56\end{array}$ & $\uparrow 74,75 \%$ \\
\hline & $\begin{array}{c}\text { Continuo } \\
\text { us }\end{array}$ & $\begin{array}{c}21,78 \pm 2,6 \\
0\end{array}$ & $34,03 \pm 1,23$ & $\begin{array}{c}12,24 \pm \\
3,00\end{array}$ & $\begin{array}{c}\uparrow 56,20 \\
\%\end{array}$ \\
\hline \multirow[t]{2}{*}{$\begin{array}{l}\text { OF } \\
(\%)\end{array}$} & Interval & $0,45 \pm 0,02$ & $0,42 \pm 0,02$ & $\begin{array}{c}-\overline{-} \\
0,03 \pm 0 \\
03\end{array}$ & $\downarrow 6,67 \%$ \\
\hline & $\begin{array}{c}\text { Continuo } \\
\text { us }\end{array}$ & $0,46 \pm 0,02$ & $0,43 \pm 0,02$ & $\begin{array}{c}-\overline{-} \\
0,03 \pm 0 \\
03\end{array}$ & $\downarrow 6,52 \%$ \\
\hline
\end{tabular}

\section{DISCUSSION}

In table 1, it shows that the delta data (post-test minus the pre-test) MDA variable as an indicator of the degree of oxidative stress at both interval training and continuous 
training decreases while the SOD variable as an indicator of antioxidant enzyme capacity, both at interval and continuous training has increased. This means that the adaptation of interval training and continuous training can reduce the degree of oxidative stress and has the effect of increasing the antioxidant enzyme capacity respectively. Likewise, the variable Osmotic fragility (OF), as an indicator of the resistance erythrocyte membrane, both in interval and continuous training was decreased. This means that there was an effect of interval and continuous training adaptation on increasing the resistance of erythrocyte membrane cells.

Based on Table 2, the results obtained with sig. $0,000<\alpha$ $=0,05$, showed that the influence of interval and continuous trainings is significant towards dependent variable in the oxidative stress level decreases and both the antioxidant capacity and the resistance of erythrocyte membrane increases. This is caused by interval and continuous training with frequency theof 3 times a week, with the intensity which was increased gradually, during the training period of 8 weeks. Table 2 can also be concluded statistically between interval training and continuous training, with no significant differences toward the influence of the components of dependent variables.

From Table 3, Analysis results of Simultaneous Confidence Intervals of Interval training can be concluded as follows:

There is a significant difference between MDA level of interval training of pretest and post-test, in a case where there is a decrease of oxidative stress level caused by interval training. Oxidative stress decrease caused by interval training is at least $36,546 \mathrm{ng} / \mathrm{ml}$. There is significant differences between SOD interval training capacity of pre-test and posttest in increasing the antioxidant activities caused by interval training. The antioxidant activity increase is caused by interval training of at least $12,176 \mu / \mathrm{ml}$. There is also a significant difference between pre-test and post-test in decreasing the hypotonic solution concentration in the erythrocyte osmotic fragility caused by interval training, caused by the increase of erythrocyte membrane resistance whose increase is at least $0,010 \%$.

In Table 3, Analysis results of Simultaneous Confidence Intervals can be concluded as follows;

There is significant differences between pre-test and posttest in decreasing the oxidative stress level caused by continuous training. Average decrease of blood plasma MDA level (as indicator of oxidative stress level) caused by continuous training is at least $63,046 \mathrm{ng} / \mathrm{ml}$. There is significant differences between SOD capacity (as the indicator of antioxidant activity) of continuous training of pre-test and post-test in increasing the antioxidant activities caused by continuous training. Iincrease in Antioxidant activity is caused by continuous training of at least $10,392 \mu / \mathrm{ml}$. There is significant differences between pre-test and post-test that is caused by continuous training in decreasing the hypotonic solution concentration in the osmotic fragility, causing the increase of erythrocyte membrane resistance average caused by continuous training of at least $0,010 \%$.

\section{Discussion of the results of oxidative stress levels}

In this research, blood plasma MDA level (as indicator of oxidative stress level) that is malondialdehyde, is lipid peroxidation in the body because of free radicals showing how the oxidative stress level occur. Intensity training or high intensity causes the free radicals that is considered as the damage cause of the cells such as muscle and heart [4]. High free radicals that are not balanced by antioxidant increase will cause stress at cells called oxidative stress [4]. Training with high intensity will increase the reactive oxygen formation and species nitrogen (RONS), in this case produce an imbalance between oxidant and antioxidant. It occurs at anaerobic and aerobic trainings [10]. Training done with appropriate dosage, will also lead to the high radicals formed at the body but the body adaptation towards training will be able to form antioxidant substance so as to overcome the formed free radicals.

According to Sandeep and Hassan, high intensity interval training for 8 weeks produces aerobic capacity increase and decreases the peroxidation lipid [11]. Aerobic training for 12 weeks causes the CAT and SOD level increase as indicator of antioxidant status increase, and both the MDA level as the indicator of oxidative stress decreases [12]. Cunningham, et al, studied about the influence of training sprint, twice a week, for 12 weeks at mouse, obtained results of MDA level decrease. It proved that the training sprint in high intensity is able to decrease the oxidative stress level [13]. The results of Lambertucci, et alstated that aerobic training is able to decrease TBARS (81\%) and increases the antioxidant enzyme activities such as $\mathrm{Cu}, \mathrm{Zn}$-SOD [14]. Research results of Araújo, et al (2013) stated that, with aerobic training, 5 times a week, for 8 weeks obtained the antioxidant enzyme activity increase (superoxide dismutase, Catalase and glutathione peroxidase), and MDA level decrease in Training adaptation causing the oxidative stress adaptation at muscle cell [15]. From the research, it is known that the impact of adaptation of interval training or aerobic continuous training causes the oxidative stress decrease with a decrease in blood plasma MDA level and oxidative stress at muscle cell.

In this research, the MDA level pre-test results between interval training and continuous training group, have no significant differences. It showed that initial condition of oxidative stress between training interval and continuous training groups are not different significantly. At the testing results between pre-test and post-test of MDA level, either at interval training or continuous training group, there is significant differences, and results at post-test showed a decrease. It showed that adaptation of interval training and continuous training are able to increase the antioxidant capacity in the body, hence able to overcome the free radicals occurrence, especially because of physical training done.

Results of blood MDA level delta between interval training and continuous training groups showed no significant differences. The results showed sig. $0,403<\alpha=0,05$ and that interval training and continuous training are good in adaptation of training hence able to increase the antioxidant to overcome the formed free radicals and also, the oxidative stress can be decreased. Based on Table 4 obtained, it showed that the sample in decreasing the oxidative stress level is more effective by continuous training of $13,49 \%$, while at interval training it's $7,59 \%$.

\section{Discussion of the results of the antioxidant enzyme capacity}

In this research, blood plasma SOD, superoxide dismutase, activity (as indicator of antioxidant enzyme capacity),) is 
primary antioxidant enzyme in body that is very prominent [16]. In the research, the SOD activities is used as the indicator of antioxidant indicators in the body. Antioxidant is the compound which is in low level, serving to prevent and suspend the bio molecular oxidation. The compound reacts with free radical (RONS) or prevent the formation of new free radicals [17]. There are two antioxidant namely; Endogenous antioxidant, that includes superoxide dismutase (SOD), catalase, glutathione peroxidase and glutathione enzymes and Exogenous antioxidants which are obtained from diet including vitamin $\mathrm{E}$, vitamin $\mathrm{C}$, coenzyme q10 and carotenoids [4].

Sport training is known to be able to increase the antioxidant production such as, catalase (CAT), superoxide dismutase (SOD), and Glutathione Sulfur Hydroxyl (GSH) [5] [16]. During sports, the enzymatic endogenous antioxidant and diet rich in antioxidant, they are able to decrease cytokine production by neutralizing directly the RONS. Resistance training done continuously decreases the level of hydrogen peroxide in the mitochondria, hence leading to decrease in oxidative stress and increasing the antioxidant defense system [7] [18]. Clarkson and Thompson, stated that chronic training is able to increase antioxidants [19]. The previous research from Sen and Ji (in Gul, 2003:53), shows aerobic training, if done regularly, is able to increase antioxidant defense. Clarkson and Thompson found out that in a trained runner, the erythrocyte enzyme activity level (superoxide dismutase, glutathione peroxidase, and catalase) is higher than untrained subjects [19]. Training done irregularly causes more oxidant than antioxidant so the oxidative stress will occur.

High intensity training adaptation intermittently at the football athletes increase the activity of CAT and SOD enzyme as the indicator increases the antioxidant status activity [1], while according to Sandeep and Hassan, high intensity training for 8 weeks causes the increase of maximum aerobic capacity and decrease the peroxidation lipid [11]. Aerobic training for 12 weeks causes the increase of CAT and SOD level as indicator of antioxidant capacity increases and there is a decrease of MDA level as the indicator of oxidative stress decrease [1]. aerobic training is able to decrease the TBARS $(81 \%)$, and increase the antioxidant enzyme activities such as $\mathrm{Cu}, \mathrm{Zn}-\mathrm{SOD}$ [17]. Aerobic training 5 times a week, for 8 weeks, there is increase of antioxidant enzyme activities (superoxide dismutase, Catalase and glutathione peroxidase), and MDA level decreases. Moderate level intensity continuous training is able to increase the antioxidant capacity [20].

The influence of interval and continuous training to the blood plasma SOD capacity as the indicator of antioxidant status obtained results that the pre-test results of blood plasma SOD capacity between the interval and continuous training group had no significant differences. It showed the antioxidant status at both group are of the same relative. The testing results of blood plasma SOD capacity between pre-test and post-test showed significant differences at both treatment groups. It showed that interval and continuous training done, produce training adaptation towards the antioxidant capacity increase, which is sufficient to increase the antioxidant activities in body.

Delta results of blood plasma SOD capacity between the interval and continuous training groups showed that there was no significant differences, obtained by sig. $0,403<\alpha=0,05$. It showed that interval and continuous training is equivalently good so as to increase the antioxidant to overcome the formed free radicals so the oxidative stress can be decreased.

Based on Table 4, the research, based on the samples obtained, antioxidant capacity increases more effectively, caused by interval training at an average of $74,75 \%$, while by continuous training rata-rata 56,20\%. The interval training causes more production of free radicals than continuous training. The free radical increase trigger the antioxidant defense system and produces more endogenous antioxidant as the form of adaptation.

3.Discussion of the results of the resistance of erythrocyte membrane.

In this research, we talk of osmotic fragility of erythrocyte as indicator of the resistance of erythrocyte membrane. Hematopoiesis process occurs at the spinal cord. Reticulocyte, as the premature form of erythrocyte, will experience maturation and form erythrocyte with diameter of $8 \mu \mathrm{m}$, with biconcave discus in 120 days old cell [21]. Erythrocyte is a main component of blood after leucocyte, thrombocyte and plasma [22].

Erythrocyte membrane is permeable toward water molecule (H2O) because of the protein transport AQP1 [22]. Erythrocyte, which is entered into hypertonic solution, will experience cell shrinkage because more water out draws into the cell. If the erythrocyte is placed at the hypotonic environment, then osmosis willoccur outside the cell that will cause the cell to distend. If the plasma cell is unable to hold high pressure into the cell because of the reach of critical volume, then the cell will break and hemoglobin will be released [23].

Osmotic fragility test assesses the erythrocyte lysis because of osmotic stress. The erythrocyte osmotic fragility level is influenced by the comparison of cell area surface to the cell volume. The osmotic fragility increase is also influenced by free radical which becomes one of the causes for the erythrocyte damage. Brites, said that free radical has a role toward osmotic fragility of erythrocyte [24].

During the physical activities, mechanical trauma towards erythrocyte is caused by muscle contraction. Besides that, during the physical activities, the body temperature increases. The body liquid lacks, hemoconcentration and oxidative stress that becomes the causes of hemolysis of erythrocyte during training. [25]. Physical activity loads done regularly gives the body adaptation toward the change of the anti-free radical production and ability to overcome the free radicals produced by the physical activities [25].

Results of Chou, et.al, cycling interval training, 5 days a week, 30 minutes, average intensity $60 \%$ VO2Maks, during 5 weeks, can improve the aggregation, osmotic fragility and decrease the erythrocyte cell damage [26]. Chou, et.al, also studied about the continuous training with moderate intensity (MCT) [7]. After training 5 times a week, 5 weeks obtained the increase results of $\mathrm{VO} 2$ max and erythrocyte osmotic fragility decreased which means there is increase of erythrocyte membrane resistance. The results done by Azeez, showed the aerobic training results with moderate intensity increases the erythrocyte osmotic resistance [27]. Mustafa, Et. $\mathrm{Al}$, run training with moderate intensity at wistar rate, each day, 30 minutes, for 4 weeks caused the decrease of muscle cell damage and the increase of erythrocyte osmotic resistance 
[28]. Sugiharto, concluded that the aerobic activity has potential towards erythrocyte osmotic fragility [29]. To prevent the physical activity, one should use the appropriate dosage and consider the nutrient aspect, especially those that contain anti free radical substance, such as those containing vitamins $\mathrm{C}$ and $\mathrm{E}$.

In the research obtained, the influence of interval and continuous training toward osmotic fragility as the indicator of erythrocyte membrane resistance at the osmotic fragility pretest (FO) between interval training and continuous training, had no significant differences. It showed the initial condition of resistance for the erythrocyte cell membrane between treatment group of interval and continuous run is not different from each other. At the test between pre-test and post-test of osmotic fragility, either at interval or continuous training groups, there is significant differences. It showed that interval and continuous training adaptation is able to increase the erythrocyte membrane resistance, hence a decrease in the liquid concentration (hypotonic) still able not to break. Osmotic fragility test assesses the erythrocyte lysis because of osmotic stress. If the erythrocyte is placed at a hypotonic environment, then osmosis will occur from outside into the cell making the cell distend. If the plasma membrane is unable to hold the high pressure of inter cell because the achievement of critical volume, then the cell will be broken.

Delta results of osmotic fragility between interval and continuous training groups showed no significant differences, obtained by sig. $0,403<\alpha=0.05$. It showed that interval and continuous trainings are equivalently good in improving the resistance of erythrocyte membrane. Although statistically no differences between interval and continuous trainings toward the increase of the resistance of erythrocyte membrane, based on the sample in the research, there is effectiveness differences. Based on Table 4, at interval training, the decrease average for osmotic fragility test was $6.67 \%$, while continuous training was $6.52 \%$. It means that interval training is more effective in improving the erythrocyte membrane resistance.

\section{CONCLUSIONS}

The research conclusions are; (1) Interval and continuous trainings decrease the oxidative stress level and increase both the antioxidant enzyme capacity, and the resistance of erythrocyte membrane. ; (2) Interval and continuous training have no significant differences in decreasing the oxidative stress level, increasing the antioxidant enzyme capacity, and improving the resistance of erythrocytemembrane. ; (3) In the research samples, the continuous training is more effective in decreasing the oxidative stress level, with the decrease average of $13,49 \%$. Interval training is more effective in improving the antioxidant enzyme capacity, with increase in average of $74-75 \%$. Interval training is more effective in improving the resistance of erythrocyte membrane, with an average increase average of $6.67 \%$.

\section{REFERENCES}

[1] Escobar, M., Oliveira, M. W. S., Behr, G. A., Zanotto-Filho, A., Ilha, L., Cunha, G. D. S., \& Moreira, J. C. F. (2009). Oxidative stress in young football (soccer) players in intermittent high intensity exercise protocol. Journal of Exercise Physiology, 12(5), 1-10.

[2] Corbin CB, Welk GJ, Corbin WR, Welk KA.(2009). Conceptsof Fitness \& Wellness: A Comprehensive Lifestyle Approach.3 rd ed.New York, NY: McGraw -Hill.
[3] Cooper, C.E., Vollaard, N.B.J., Choueiri, T., and Wilson, M.T. (2002). "Exercise, Free Radical and Oxidative Stress". Biochemical Society Transactions. Vol 30 No 2, pp. $280-285$.

[4] Powers, S. K., \& Jackson, M. J. (2008). Exercise-induced oxidative stress: cellular mechanisms and impact on muscle force production. Physiological reviews, 88(4), 1243-1276.

[5] Araujo M.B. de, Voltarelli, F.A., Contarteze, R.V.L., Gobatto, F.B.M., and Mello, M.A.R de. (2009). "Oxidative Stress in Rats Exercised at Different Intensity". Jounal of Chinese Clinical Medicine. Vol 4 No 1, pp. 11-18

[6] Daniel, R.M., Stelian, S., and Dragomir, C. (2010). "The effect of Acute Physical Exercise on The Antioxidant Status of The Skeletal and Cardiac Muscle in The Wistar Rat". Romanian Biotechnological Letters. Vol 15 No 3, pp. 56-61.

[7] Leeuwenburgh, C., \& Heinecke, J. W. (2001). Oxidative stress and antioxidants in exercise. Current medicinal chemistry, 8(7), 829-838.

[8] Wresdiyati, T., Mamba, K., Adnyane, I., \& Aisyah, U. S. (2002). The effect of stress condition on the intracellular antioxidant copper, zincsuperoxide dismutase in the rat kidney: an immunohistochemical study. Hayati, 9(3), 85-88

[9] Jewett, S. L., Eddy, L. J., \& Hochstein, P. (1989). Is the autoxidation of catecholamines involved in ischemia-reperfusion injury?. Free Radical Biology and Medicine, 6(2), 185-188.

[10] Bloomer RJ \& Smith WA. (2009). Oxidative stress in response ti aerobic and anaerobic power testing: Influence of exercise training and carnitine supplementation. Research in sport medicine; 17:1-16.

[11] Sandeep ,H. S and Hassan, M. A (2013). "Effect of High IntensityInterval Training on Malondialdehyde And Aerobic Capacityof MalePhysical Education Students". International Journalof Current Advanced Research Research Vol.2, Issue,.57 - 59,

[12] Ajabi, F.J, Mohammad R Z, AsgharT, (2013). "Influence of aerobic training on red cell antioxidants defense, plasma malondialdehyde capacity in patients multiple sclerosis". International Research Journal of Appliedand Basic Sciences Vol, 4 (7): 1757-1761

[13] Cunningham P, Geary M, Harper R, Pendleton A, Stover S, (2005) “ High Intensity Sprint Training Reduces Lipid Peroxidation InFastTwitch Skeletal Muscle". Journal of Exercise Physiologyonline; $8(6): 18-25$.

[14] Lambertucci, R. H., Levada-Pires, A. C., Rossoni, L. V., Curi, R., \& Pithon-Curi, T. C. (2007). Effects of aerobic exercise training on antioxidant enzyme activities and mRNA levels in soleus muscle from young and aged rats. Mechanisms of ageing and development, 128(3), 267-275.

[15] Steinbacher, P., \& Eckl, P. (2015). Impact of oxidative stress on exercising skeletal muscle. Biomolecules, 5(2), 356-377.

[16] Kumalaningsih, S. (2007). Antioksidan Sumber dan Manfaatnya. take from: http://antioxidancentre. com/html.

[17] Weseler, A. R., \& Bast, A. (2010). Oxidative stress and vascular function: implications for pharmacologic treatments. Current hypertension reports, 12(3), 154-161.

[18] Peake, J. M., Suzuki, K., \& Coombes, J. S. (2007). The influence of antioxidant supplementation on markers of inflammation and the relationship to oxidative stress after exercise. The Journal of nutritional biochemistry, 18(6), 357-371.

[19] Clarkson, P. M., \& Thompson, H. S. (2000). Antioxidants: what role do they play in physical activity and health?. The American journal of clinical nutrition, 72(2), 637S-646S.

[20] Poblete Aro, C. E., Guzmán, R., Antonio, J., Soto Muñoz, M. E., \& Villegas González, B. E. (2015). Effects of high intensity interval training versus moderate intensity continuous training on the reduction of oxidative stress in type 2 diabetic adult patients: CAT. Medwave, 15(07).

[21] Pasini, E. M., Kirkegaard, M., Mortensen, P., Lutz, H. U., Thomas, A. W., \& Mann, M. (2006). In-depth analysis of the membrane and cytosolic proteome of red blood cells. Blood, 108(3), 791-801

[22] de Oliveira, S., \& Saldanha, C. (2010). An overview about erythrocyte membrane. Clinical hemorheology and microcirculation, 44(1), 63-74.

[23] Mosca, A., Paleari, R., Ivaldi, G., Galanello, R., \& Giordano, P. C. (2009). The role of haemoglobin A2 testing in the diagnosis of thalassaemias and related haemoglobinopathies. Journal of Clinical Pathology, 62(1), 13-17. 
[24] Brites, F. D., Evelson, P. A., Christiansen, M. G., Nicol, M. F., Basílico, M. J., Wikinski, R. W., Llesuy, S. F. (1999). Soccerplayers under regular training show oxidative stress but an improved plasma antioxidant status. Clinical Science, 96(4), 381-385.

[25] Șentürk, U. K., Gündüz, F., Kuru, O., Aktekin, M. R., Kipmen, D., Yalçin, O., \& Başkurt, O. K. (2001). Exercise-induced oxidative stress affects erythrocytes in sedentary rats but not exercise-trained rats. Journal of applied physiology, 91(5), 1999-2004.

[26] Chou, S. L., Huang, Y. C., Fu, T. C., Hsu, C. C., \& Wang, J. S. (2016). Cycling Exercise Training Alleviates Hypoxia-Impaired Erythrocyte Rheology. Medicine \& Science in Sports \& Exercise, 48(1), 57-65.
[27] Azeez, O. I., \& Oyewale, J. O. (2010). Effects of swimming exercise on erythrocyte osmotic fragility of the rainbow lizard (Agama agama). Russ. J. Herpetol. 7, 1-85.

[28] Mustafa Kelle, Hüda Diken (1999). "Effect of Exercise on Blood Antioxidant Status and Erythrocyte Lipid Peroxidation: Role of Dietary Supplementation of Vitamin E" Tr. J. of Medical Sciences 29, 95-100

[29] Sugiharto. (2005) . Fragilitas Osmotik Eritrosit pada aktivitas Fisik Aerobik. Jurnal Iptek Olahraga. Vol 7, No 3, September 2005 